\section{SEVERITY INDEX FOR VEHICLE DRIVERS AT FRONTAL IMPACT INTO RIGID BARRIER JOZEF KMEC, STELLA HREHOVA}

Faculty of Humanities and Natural Sciences, Presov University, Presov, Slovakia,

Faculty of Manufacturing Technologies with a seat in Presov, Technical University of Kosice

\section{DOI : 10.17973/MMSJ.2019_03_201876}

e-mail : jozef.kmec@unipo.sk

This article deals mainly with frontal impacts of vehicles of various classes (small cars, middle class, Pick ups/SUVs, etc.) into a fixed barrier according to the NHTC (National Car Traffic Safety Administration) for the US-NCAP (New Car Assessment Program). The acceleration record was processed from the accelerometer through the Logger Pro program package. If the accelerometer was firmly connected from the car's rear floor, the deformation path (maximum deformation) or plastic deformation was calculated. If the accelerometer was firmly connected from the manikin's head, the severity index ( $\mathrm{S}$ index) was calculated to increase the active and passive safety of the passengers

KEYWORDS

Deformation path, active and passive safety, severity index (SI index)

\section{INTRODUCTION}

The development of technology in the past century has enabled the development of stronger and hence faster means of transport. Higher performances and speeds also brought dark spots - traffic accidents. The leading department dealing with vehicle safety was established in the United States of America. On the basis of the data obtained, information from traffic accidents was analysed and the construction errors of most of the cars produced at that time were evaluated. At the same time, the basic criteria for crew protection have been laid down and are still in force today. These rules have been extended to Europe and other parts of the world, and different standards and regulations for vehicle design have been enacted from the point of view of their safety. In general, vehicles are assessed for active and passive safety [VIk 2003].

\section{VEHICLE SECURITY}

Everything that can prevent accidents is called active safety. This includes precise steering, good chassis characteristics, efficient brakes, a good performance engine and others [VIK 2003]. Passive safety means measures whose purpose is to alleviate the consequences of a traffic accident. In common cars, the following elements appear: safety belts, airbags, deformation zones, deformable sheet metal structures, plastic parts and composites [Vlk 2003].
3

The human body defines biomechanical limits that can be resisted without more or less serious damage. By analysing traffic accidents and crash tests, various criteria were set for assessing the effect of critical peak acceleration on human body damage. Head injury is the most common and most dangerous consequence of damage to the human body. Head injuries occur in $70 \%$ of traffic accidents. For peak head acceleration, a so-called WSU curve (Wayne State University) was determined to indicate the head-to-head translational delay, depending on the duration of action (Fig. 1). Values above the curve are considered life-threatening, under the curve as bearable. The critical peak acceleration of the human head is $80 \mathrm{~g}$ for $3 \mathrm{~ms}$ [Vlk 2003]. From the WSU curve, the SI Index (Severity Index) was experimentally determined. The critical value of this index is 1000 [Vlk 2003] and is calculated according to the relationship

$\left.S I=\int_{0}^{T} a_{r}(t)^{2,5} \mathrm{~d} t\right)$

where $a_{\mathrm{r}}(t)$ is the result acceleration of the head in gravity acceleration units $\left(1 \mathrm{~g}=9,81 \mathrm{~ms}^{-2}\right)$ [Seben 2016] and $T$ denotes the impact time in (s). Head injury is further assessed by the Head Injury Criterion (HIC), which is calculated according to the relationship [VIk 2003]

$H I C=\sup _{t_{1}, t_{2}}\left[\left[\frac{1}{t_{2}-t_{1}} \int_{t_{1}}^{t_{2}} a_{r} \mathrm{~d} t\right]^{2,5}\left(t_{2}-t_{1}\right)\right]$

where $t_{1}, t_{2}$ are time moments during the duration of the impact for which the HIC value is the maximum. Measured time values are specified in seconds.

In impact crash tests, other parts of the human body are also analysed. The test dummies measure not only acceleration but also speed or compression. Biomechanical limits are also prescribed for the neck, femur, chest and others. Their values can be found in the rules of the European Economic Commission (EHK R 94) [Regulations 2010] for frontal impact, respectively (EHK R 95) in the event of a side impact.

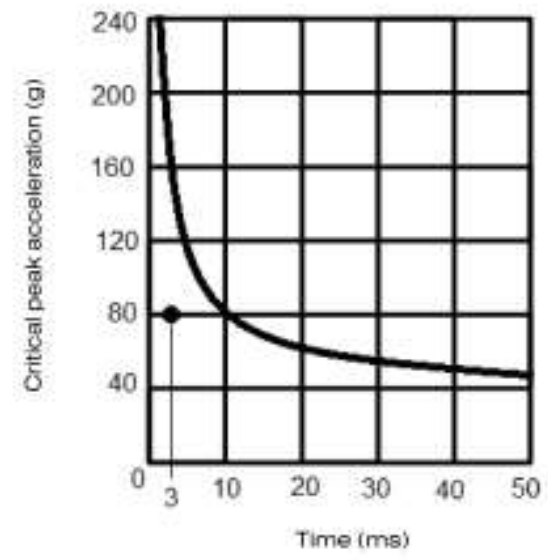

Figure 1: WSU curve 
Deformation zones are used in automobiles to protect the car crew in an accident from injuries [Regulation 2010]. The task of the deformation zones is to absorb kinetic energy respectively deformation work to protect the crew compartment [Vlk 2003], [Seben 2016], [Evin 2016]

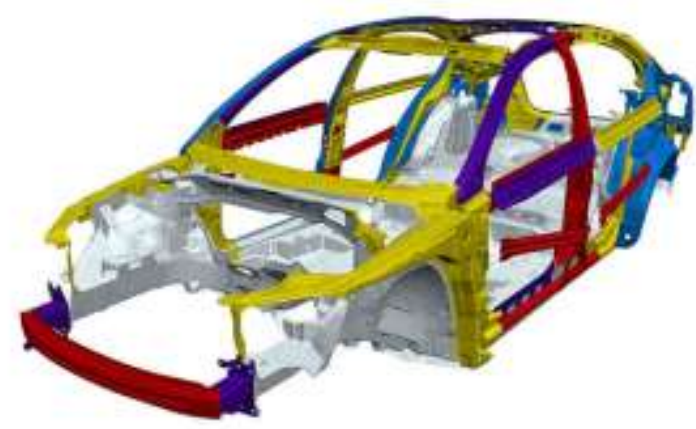

Figure 2: Location of deformation zones on the bodywork

In Fig. 2 we have drawn individual deformation zones on the bodywork. Red color refers to the most rigid parts of the car and they are used mainly in pillars and doors to protect passengers in a car accident. The yellow and violet colors feature less solid materials than red ones, which in the case of a higher speeds accident have the task of deforming so as not to touch the interior of the car [Blaták 2010], [RCAR 1999].

\section{GETTING DATA FROM FRONT IMPACT TEST}

Data for the Severity index were obtained from a frontal impact test on a solid barrier with full coverage at a speed of 56,63 $\mathrm{kmh}^{-1}$ (according to NCAP (New Car Assessment Program) [NCAP 2017]. In Fig. 3 we also have the NISSAN Frontier CREW CAB 4 AWD 4 Door Truck, which belongs to the highest class of vehicles

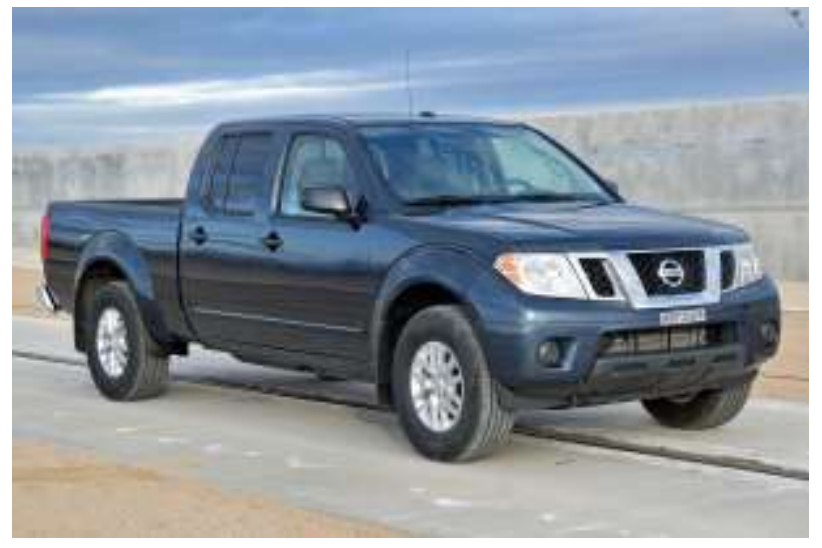

Figure 3: Pre-Test Right View of Test Vehicle Nissan Frontier by NCAP [6]

\section{RECORDING FROM THE ACCELEROMETER}

The record was processed from an accelerometer that is firmly connected to the vehicle floor at the rear of the bodywork. Accelerometer is a sensor of non-electric quantities, which converts the detected quantity into an electrical signal and is

subsequently processed and evaluated. This electrical signal is characterized as a continuous analogue signal and then the $A / D$ converter is sampled to discrete values. Recording from accelerometer at impact tests due to significant signal oscillation must be filtered by the CFC 60 filter (Channel Frequency Class) [Cichos 2006]. Recording from the head of the dummy due to a small signal oscillation can be filtered by the CFC 1000. Table 1 records the most common types of filters used in this article.

Table 1: Types of filters

\begin{tabular}{|c|c|c|c|}
\hline Filter type & \multicolumn{2}{|c|}{ Filter parameters } & $\begin{array}{c}\text { Use the } \\
\text { filter }\end{array}$ \\
\hline \multirow{3}{*}{ CFC 60} & $\begin{array}{l}3 \mathrm{~dB} \text { limit } \\
\text { frequency }\end{array}$ & $100 \mathrm{~Hz}$ & \multirow[t]{3}{*}{$\begin{array}{l}\text { Structure } \\
\text { acceleration }\end{array}$} \\
\hline & $\begin{array}{l}\text { Stop } \\
\text { damping }\end{array}$ & $-30 \mathrm{~dB}$ & \\
\hline & $\begin{array}{l}\text { Sampling } \\
\text { frequency }\end{array}$ & $\begin{array}{l}\text { At least } \\
600 \mathrm{~Hz}\end{array}$ & \\
\hline \multirow{3}{*}{ CFC 1000} & $\begin{array}{l}3 \mathrm{~dB} \text { limit } \\
\text { frequency }\end{array}$ & $1650 \mathrm{~Hz}$ & \multirow{3}{*}{$\begin{array}{l}\text { Acceleration } \\
\text { at the head } \\
\text { of the } \\
\text { dummy }\end{array}$} \\
\hline & $\begin{array}{l}\text { Stop } \\
\text { damping }\end{array}$ & $-40 \mathrm{~dB}$ & \\
\hline & $\begin{array}{l}\text { Sampling } \\
\text { frequency }\end{array}$ & $\begin{array}{l}\text { At least } \\
10 \mathrm{kHz}\end{array}$ & \\
\hline
\end{tabular}

In order to be able to measure impact tests, the signal processing must be performed under predetermined conditions. These regulations are laid down in SAE J211-1: Instrumentation for Impact Test, Part 1, Electronic Instrumentation. All the quantities occurring in the impact test are specified in this standard.

\section{ACHIEVED RESULTS AND THEIR DISCUSSION}

This article deals primarily with personal sport cars made of materials such as steel and its alloys, aluminium and its alloys, and composite materials that are mainly used in sports specs. The front impacts of vehicles of different vehicle classes are described Table 2 (small cars, middle class, Pick up/SUV, etc.) into a rigid barrier according to NCAP. So we can say that the Nissan Frontier belongs to the highest class of vehicles whose behavior is discussed in detail in this article at frontal impact into rigid barrier.

In the following, we also clarify the meaning of the individual labels appearing in Fig. 4, 5.

In Fig. 4:

- deformation path in $(\mathrm{m})$ (here we get the double integration of acceleration according to time) in ( $\mathrm{m}$ ) means the size of the deformation of the vehicle body, in the graph depicted on the left axle y. (In this article, we will understand under acceleration the deceleration of a vehicle's impact into rigid barrier);

- speed in $(\mathrm{m} / \mathrm{s})$ means the speed of the vehicle in the case of a frontal collision into rigid barrier, in a graph on the right-hand axis y;

- deceleration floor filter in (g) means the filtered deceleration course with the CFC 60 filter and measured by an 
accelerometer located on the floor at the rear of the vehicle, in a graph plotted on the right-hand scale y.

- deceleration floor in (g) means true unfiltered deceleration with oscillations, in a graph on the right-hand axis $y$.

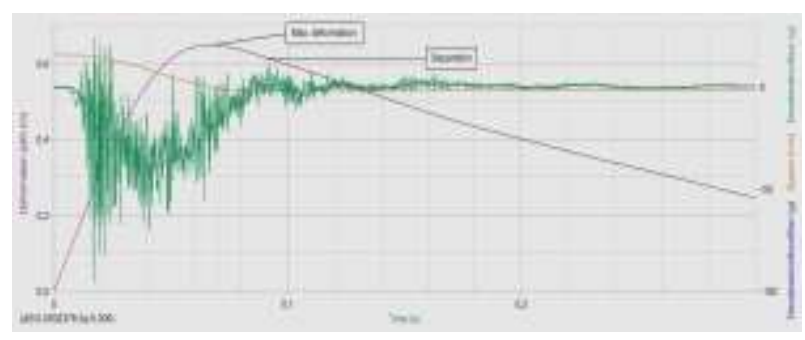

Figure 4: Dependence of the deformation path in $(\mathrm{m})$ from time in $(\mathrm{s})$ (see the left axis $y$ in the graph). Depending on the speed in (ms-1) from time in (s), at the same time deceleration floor filter in (g) from time in

(s) and deceleration floor at the same time in (g) from time in (s) (see the right axis y in the graph).

In Fig. 5:

- deceleration head in (g) means the true deceleration measured at the head of the dummy with oscillations

- deceleration head filter means deceleration in $(\mathrm{g})$ measured at the head of the dummy and filtered off the oscillations by the CFC 1000 filter.

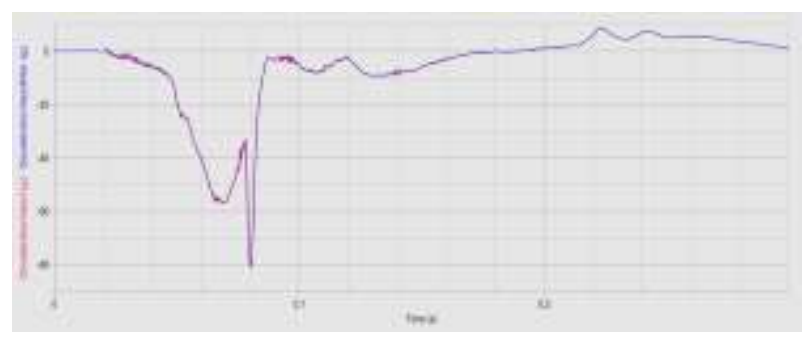

Figure 5: Dependence of the true deceleration head in (g) measured at the head of the dummy and deceleration head filter filtered from the oscillations by the CFC 1000 filter on time in (s)

The Fig. 4 shows that the vehicle achieves maximum deformation (elastic and plastic strain) of $0,65 \mathrm{~m}$ in time $0,07 \mathrm{~s}$. In relation to speed (this is integration of acceleration by time) at the same time, the vehicle should move from positive to negative value - it should have a zero speed. Furthermore, the speed decreases until it reaches the global minimum and at this point the vehicle is separated from the barrier.

In relation to the deformation path, after the end of the impact of the vehicle into rigid barrier, the front part of the vehicle will be deformed by the size of the plastic deformation, this value being $0,62 \mathrm{~m}$. In relation to deceleration, at the same moment the deceleration passes through the $x$-axis - the sign changes, i.e. it is marked with a zero value. In the case of a frontal impact (Fig. 2), the soft parts of the construction work at first, to protect pedestrians (plastic bumper), then the actions in the case of minor collisions at low speeds (the deformation member), then the greater force loads result in an exceeding of the bearing capacity of the deformation members to deform the bodywork with the engine compartment. In the case of a deceleration from the start of the coordinate system, the deceleration changes according to the parts of the structure encountered by the vehicle within the deformation zones. Some parts of the car can be deformed more easily and the deceleration is smaller, while the deformation of other parts is the opposite and the deceleration is greater [Kluvánek 2010].

For the Nissan Frontier, a more pronounced deceleration increase can be seen at $0,044 \mathrm{~s}$, which corresponds to a deformation of $0,55 \mathrm{~m}$ and reaches a value of $-40 \mathrm{~g}$, and that's already in the body area of the engine compartment. At $0,044 \mathrm{~s}$, the deceleration begins to decrease until it reaches a zero value at $0,084 \mathrm{~s}$ when the vehicle is separated from the barrier and the vehicle moves in the opposite direction to the direction of impact. The deceleration head filter (measured at the head of the dummy, where the oscillations are filtered by the CFC 1000 filter), as a function of the time that can be observed in Fig. 5, reaches its maximum at $-80 \mathrm{~g}$ at $0,08 \mathrm{~s}$.

The delay the maximum deceleration of the dummy and its slight increase and then a significant increase (up to $-80 \mathrm{~g}$ ) in relation to the deceleration of the vehicle is probably due to the attachment of the safety belt to the manikin. Clarification of the forces or accelerations that act on the manikin's head is more complicated. If the manikin has a seat belt fastened, its body (hull and head) will move from the moment of impact to the original speed until the belt becomes jammed and consequently jammed with the dummy respectively with the head on which the accelerometer is located. At that moment, braking will start very intensively, because there will be a shorter stroke for the braking. This will greatly increase the deceleration and the force acting on the dummy's head.

As a critical peak acceleration (deceleration) of the human head, $80 \mathrm{~g}$ is given for $3 \mathrm{~ms}$ [Vlk 2003], [Blaták 2010]. In our case this criterion is not met (measured deceleration values usually does not reach $-80 \mathrm{~g}$ ) and therefore the probability of survival would be achieved even though the brain is from soft tissue.

Table 2: Types of filters

\begin{tabular}{|c|c|c|c|c|}
\hline Vehicles & $\begin{array}{l}\text { Plastic } \\
\text { defor- } \\
\text { mation } \\
\text { (m) }\end{array}$ & $\begin{array}{l}\text { Max. } \\
\text { decele- } \\
\text { ration in } \\
\text { (g) at } \\
\text { defor- } \\
\text { mation } \\
\text { (m) }\end{array}$ & $\begin{array}{l}\text { Max. dece- } \\
\text { leration of } \\
\text { dummy's } \\
\text { head in (g) }\end{array}$ & $\begin{array}{c}\text { Vehicle } \\
\text { class } \\
\text { (SI } \\
\text { index) }\end{array}$ \\
\hline $\begin{array}{l}\text { Nissan } \\
\text { Note }\end{array}$ & 0,65 & -44 at 0,5 & -52 & $\begin{array}{c}\text { Small } \\
\text { cars } \\
(\mathrm{SI} 50,0)\end{array}$ \\
\hline $\begin{array}{l}\text { Toyota } \\
\text { Yaris }\end{array}$ & 0,58 & -50 at 0,4 & -45 & $\begin{array}{c}\text { Small } \\
\text { cars } \\
(\mathrm{SI} 50,1)\end{array}$ \\
\hline $\begin{array}{l}\text { Hyundai } \\
\text { elantra }\end{array}$ & 0,6 & $\begin{array}{c}-44 \text { at } \\
0,51\end{array}$ & -48 & $\begin{array}{c}\text { Middle } \\
\text { class } \\
(\mathrm{SI} 50,0)\end{array}$ \\
\hline $\begin{array}{l}\text { Honda } \\
\text { Civic }\end{array}$ & 0,68 & -38 at 0,6 & -40 & $\begin{array}{c}\text { Middle } \\
\text { class } \\
(\mathrm{SI} 50,2)\end{array}$ \\
\hline $\begin{array}{l}\text { Buick } \\
\text { Cascada }\end{array}$ & 0,65 & -50 at 0,4 & -45 & $\begin{array}{c}\text { SUV (SI } \\
50,1)\end{array}$ \\
\hline $\begin{array}{l}\text { Buick } \\
\text { Envision }\end{array}$ & 0,64 & -40 at 0,6 & -50 & $\begin{array}{c}\text { SUV (SI } \\
50,4)\end{array}$ \\
\hline $\begin{array}{l}\text { Ford } \\
\text { Escape }\end{array}$ & 0,7 & -44 at 0,5 & -80 & $\begin{array}{c}\text { MPV (SI } \\
300)\end{array}$ \\
\hline $\begin{array}{l}\text { Nissan } \\
\text { Frontier }\end{array}$ & 0,62 & -40 at 0,55 & -80 & $\begin{array}{c}\text { Truck (SI } \\
300)\end{array}$ \\
\hline $\begin{array}{l}\text { Chrysler } \\
\text { Pacifica }\end{array}$ & 0,6 & -50 at 0,4 & -40 & $\begin{array}{l}\text { Minivan } \\
(\mathrm{SI} 50,0)\end{array}$ \\
\hline
\end{tabular}


a) Based on Table 2, it can generally be said that a vehicle in the event of a frontal impact into rigid barrier, if it deforms continuously on the longest path, the driver accelerates less and vice versa. This does not apply to the MPV vehicle and the Truck vehicle where, on a comparable deformation track, the deceleration is slightly larger for MPV than for a Truck Vehicle - probably due to a more rigid MPV structure [Evin 2016].

b) The decelerations measured by the accelerometer on the manikin's head in relation to the vehicle were higher in the MPV and Truck category - almost double the deceleration measured by the accelerometer firmly connected to the MPV rear floor and the Truck. This increase was probably due to the fastening of the safety belt on the dummy in such a way that the dummy (the hull and the head) will move for a certain amount of time from the moment of impact to the original speed until the belt becomes jammed and consequently jerks with the head of the dummy. At that point, very heavy braking will occur, because there will be a shorter stroke for braking. This will increase the acceleration on the dummy's head. Table 2 shows that the deceleration values measured on the dummy's head are also slightly lower in relation to the vehicle, and this is probably due to the attachment of the safety belt to the manikin so as to prolong the movement of the dummy and thereby accelerate slightly.

c) The critical peak acceleration of the human head is $80 \mathrm{~g}$ for $3 \mathrm{~ms}$ [Vlk 2003]. As can be seen from Table 2, measured acceleration values can be considered safe. The $\mathrm{SI}$ index for commonly used cars is 50 and the $\mathrm{SI}$ for the MPV vehicle (Ford Escape) and Truck vehicle (Nissan frontier) is 300, which are calculated according to equation (1), i.e. for those vehicles where the short-term peak of $80 \mathrm{~g}$ is measured.

d) Surprisingly, the high g value measured on the MPV dummy's head and Truck vehicle - up to twice the g value measured on the vehicles concerned - due to inappropriate fastening of the safety belts or the vehicle structure.

\section{ACKNOWLEDGMENTS}

The research work was supported by the grant KEGA 001PU4/2016 "Optimization of information and communication technologies applications in the gradual preparation of future teachers".

\section{REFERENCES}

[Blatak 2010] Blatak, O. Lectures from Subject Motor Vehicles. Brno: VUT Brno 2010

[Cichos 2006] Cichos, D. Crash Analysis Criteria Description. 2006. Available from: www.crash-network.com.

[Evin 2016] Evin, E., Tomas, M., Vyrostek, M. Laser-beam welding impact on the deformation properties of stainless steels when used for automotive applications. In: Acta Mechanica et Automatica. Vol. 10, no. 3, 2016, p. 189-194. ISSN 1898-4088.

NCAP. Report number NCAP-KAR-16-014. New car assesment program. 2017. Available from: www.nrd.nhtsa.dot.gov

Regulation (EC) No. 94 - Uniform provisions concerning the approval of vehicles with regard to the protection of occupants in the event of a frontal impact [online]. Official Journal of the European Union, 2010 (Czech), [cit. 11. 7. 2013] Available from: <http://eurlex.europa.eu/LexUriServ/LexUriServ.do?uri=OJ:L:20 10:130:0050:0100:CS:PDF>

RCAR. 1999. Available from : http://www.rcar.org/.

[Kluvanek 2010] Kluvanek, p. Road safety in terms of physics. Blog 2010. Available from:

http://kluvanek.blog.sme.sk/c/227590/Bezpecnost-cestnejpremavky-z-hladiska-fyziky.html.

[Seben 2016] Seben, V. Educating primary school students in the field of natural sciences with the use of information and communication technologies (ICT) (Polish) In: Aktywnosc poznawcza i dzialaniowa dzieci $w$ badaniach pedagogicznych. Krakow: Wydawnictwo naukowe UP, 2016, s. 214-217. ISBN 978-83-7271-979-9.

[Vlk 2003] Vlk, F. Construction of motor vehicles. 1st edition. Brno: 2003, 499 s. ISBN 80-238-8757-2.

\section{CONTACTS}

RNDr. Jozef Kmec, PhD.

Faculty of Humanities and Natural Sciences, Presov University, Ul. 17. novembra c. 15 08001 Presov, Slovakia, jozef.kmec@unipo.sk

Ing. Stella Hrehova, PhD.

Technical university in Kosice, Faculty of manufacturing technologies with seat in Presov Bayerova 1

08001 Presov, Slovakia

stella.hrehova@tuke.sk 